\title{
Use of the X-ray Computed Microtomography Technique for the Comparative Morphological Characterization of Proceratophrys bigibbosa Species from Southern Brazil
}

\author{
Francielle Ahmann ${ }^{1}$ \\ Universidade Tecnológica Federal do Paraná \\ Linha Santa Bárbara, s/n, 85601-970 Francisco Beltrão, PR, Brasil \\ E-mail: fran.ahmannehotmail.com

\section{Ivan G. Evseev} \\ Universidade Tecnológica Federal do Paraná \\ Linha Santa Bárbara, s/n, 85601-970 Francisco Beltrão, PR, Brasil \\ E-mail: evseeveutfpr.edu.br
}

\section{Rodrigo Lingnau}

Universidade Tecnológica Federal do Paraná

Linha Santa Bárbara, s/n, 85601-970 Francisco Beltrão, PR, Brasil

E-mail: rodrigolingnau@gmail . com

levgeniia levsieieva

Instituto Politécnico da Universidade do Estado do Rio de Janeiro Rua Alberto Rangel, s/n, 28630-050 Nova Friburgo, RJ, Brasil

E-mail: ievsieieva@iprj.uerj.br

\section{Joaquim T. de Assis}

Instituto Politécnico da Universidade do Estado do Rio de Janeiro Rua Alberto Rangel, s/n, 28630-050 Nova Friburgo, RJ, Brasil

E-mail: joaquimeiprj.uerj.br

\section{Haimon D. L. Alves}

Laboratório de Instrumentação Nuclear COPPE, UFRJ

Av. Horário Macedo 2030,21941-914 Rio de Janeiro, RJ, Brasil

E-mail: halves@con.ufrj.br

XXXIV edition of the Brazilian Workshop on Nuclear Physics,

Foz de Iguaçu, Parana state, Brasil

5-10 June 2011

\footnotetext{
$1 \quad$ Speaker
} 
The Proceratophrys bigibbosa species group is characterized by the presence of postocular swellings and absence of hornlike palpebral appendages. A new member of this group was described recently from southern Brazil: Proceratophrys brauni. Its body size is between the smaller Proceratophrys avelinoi and the larger Proceratophrys bigibbosa species, both living in the same region. As the external appearance of these species is very similar to each other, it is interesting to discover a specific morphological categorization through internal individuality, such as the cranium proportions, for example. In this paper, we report the preliminary results for comparative craniums morphological characterization of Proceratophrys bigibbosa species using the X-ray computed microtomography technique. Five samples of each three species, i.e. fifteen samples in total, were scanned by the Skyscan 1174 system. The 3D tomographic images were used to compare the cranium proportions. The main result is that some visible differences in the species cranium can be observed.

Keywords: X-ray microtomography, Proceratophrys bigibbosa

\section{Introduction}

In this work, we used the X-ray microtomography $(\mu \mathrm{CT})[1,2]$ as a tool for the morphological analysis of frog craniums. Three species of the Proceratophrys bigibbosa group in the Cycloramphidae family [3] were studied. This group is characterized by the presence of postocular swellings and large marginal tubercles on eyelids, and absence of hornlike palpebral appendages [3]. The three analyzed species, P. avelinoi, P. bigibbosa and P. brauni are distributed along rocky and/or muddy streams in the south of Brazil, the north of Argentina, and Paraguay $[4,5]$.

It is quite possible that a number of confusion in the museum identification has been occurred years ago. The first reason is the external appearance of these three members of the group is very similar to each other. The second is that some areas of "sympatry" (localities with overlapping incidence of two, or more species of the P. bigibbosa group) were reported recently $[3,5]$. Therefore, it could be interesting to discover a specific morphological categorization through internal characteristics, such as the cranium proportions.

Several years ago, the most common technique to study the skeleton structure was based on the complete removal of skin and musculature [6]. Alternatively to this destructive method, the so-called "diafanization" could be used. Diafanization consists in an old technique to clear whole specimens with further staining of bones and cartilages, normally used with small vertebrates. It is partially destructive method because it does not preserve the sample external appearance.

The $\mu \mathrm{CT}$ permits both the skeleton visualization with the bones on its natural position, like the second method, and to measure straightforwardly the bones geometry, like the first one. The great advantage of this work is that none of the studied samples were destroyed, or changed. 


\section{Materials and methods}

\subsection{The Frog Samples}

The specimens of P. bigibbosa, P. brauni and P. avelinoi were collected in Brazil and Argentina. In Brazil, the origin of specimens is from the municipalities of Ponte Serrada and Lebon Régis in Santa Catarina State, as well as from Altamira do Paraná and Fazenda Rio Grande in Paraná State. In Argentina, the specimens were acquired from Garuape-mí, Departamento Eldorado, Misiones.

After being caught, all specimens were sacrificed using 30\% alcohol, then covered with $10 \%$ formalin as fixative, and definitively deposited into $70 \%$ alcohol for the museum collection. Fig. 1 shows the representative specimens of P. bigibbosa, P. brauni and P. avelinoi species. It can be seen that the external morphology of three members of the group is very similar to each other, except for the dimensions.

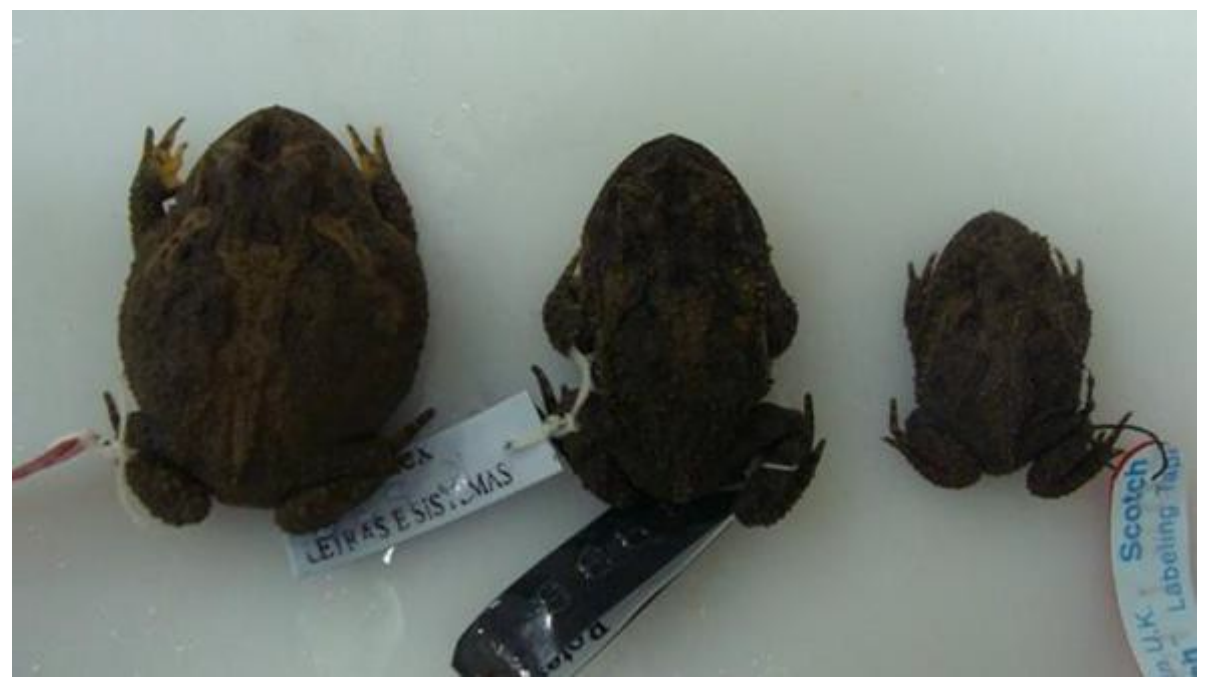

Figure 1. Typical specimens of (from left to right) P. bigibbosa, P. brauni, and P. avelinoi.

\subsection{SkyScan 1174 Tomograph}

The frogs were scanned with SkyScan 1174 [7] compact micro-CT system. It was operated at $50 \mathrm{kV}, 800 \mu \mathrm{A}$ (40 W power) with $0.25 \mathrm{~mm} \mathrm{Al}$ filter (Fig.2). During the data acquisition, the turntable rotation was done with $1^{\circ}$ step. For each specimen, 360 radiographic images from the SkyScan 11741.3 megapixel X-ray camera were binarized and stored into the computer. The camera pixel size is $41.23 \mu \mathrm{m}$. Due to the cone beam optical magnification, it corresponds to $33.28 \mu \mathrm{m}$ on the object plane. At these conditions, it took approximately $20 \mathrm{~min}$ to acquire the full set of CT projections for each specimen. 
A cardboard box was used to fix specimens onto the turntable (Fig.2). It was a critical stage of the study, because the turntable rotation could provoke small displacements of the scanned object. Unfortunately, as a result two blurred CT reconstructions of P. avelinoi were achieved.

The 2D $1024 \times 1024$ pixel CT slices were reconstructed using NRecon 1.6.0.3 code. On this step, the area of interest (i.e. the region where the cranium appears on the radiographic images) was selected to avoid the computer treatment of useless information. In addition, the convenient threshold was slightly adjusted for reconstruction of only the bone component of the specimen (according to the aim of the analysis).

Then, the 3D cranium images were rendered from 2D CT slices using the 3D DOCTOR code. These images were used both for the visual qualitative analysis and for quantitative measurements of cranium's geometrical proportions.

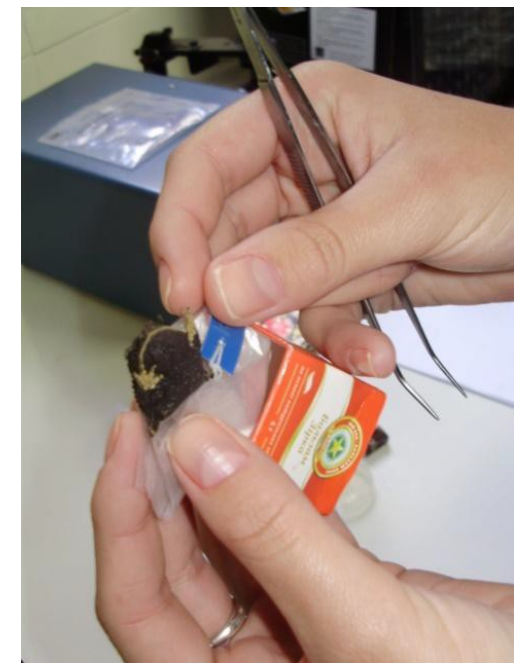

a

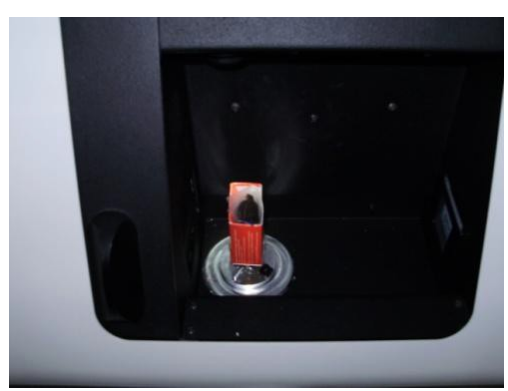

C

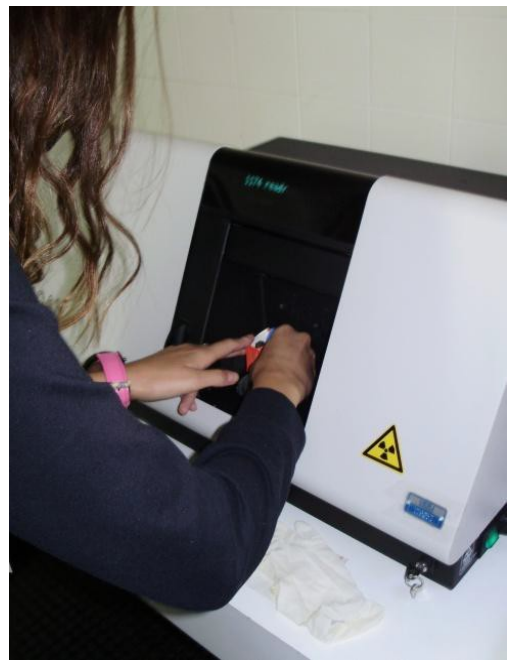

b

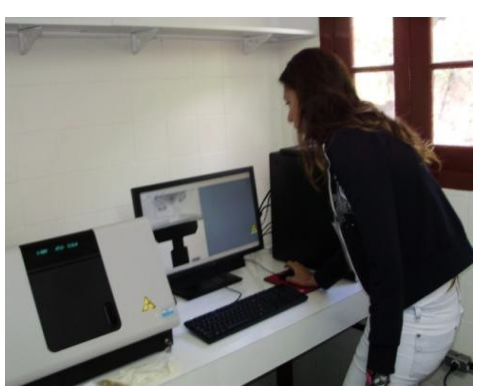

d

Figure 2. Step by step frog scanning by SkyScan 1174:

a Fixation in the cardboard;

b,c Positioning on the turntable;

d Scanning. 


\section{Results and discussion}

The main result of this work is that $\mu \mathrm{CT}$ permits to distinguish $P$. avelinoi, $P$. bigibbosa and $P$. brauni species from museum collections through a visual qualitative analysis of the cranium images. It is possible due to some evident morphological differences of the three species.

In the frontal view (not shown), for example, there are obvious differences in the projection of tubercles above the ocular socket between $P$. brauni and $P$. bigibbosa, being much more apparent in P. brauni. In the dorsal view (see Fig.3), it could be observed that all the region of the frontal parietal bone, including its crest lateral, in the case of $P$. avelinoi is smoother than for the other two species. In addition, a bigger projection of the parietal crest reaching the squamosal could be observed for P. bigibbosa.

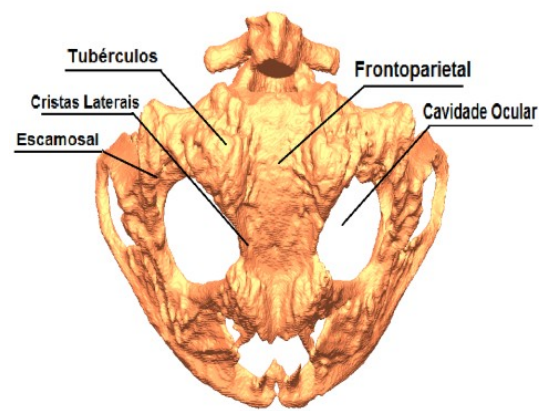

a

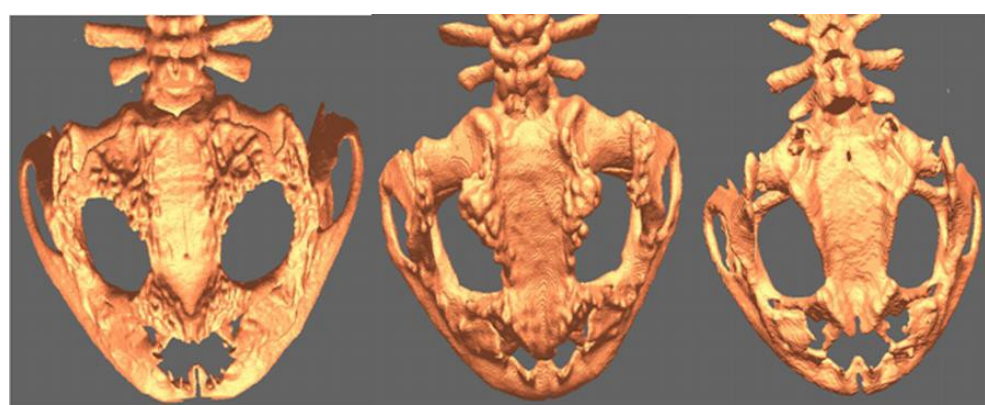

b
C

Figure 3. The bone nomenclature (a), and the orthogonal projections of the cranium 3D $\mu \mathrm{CT}$ images in the dorsal view: P. bigibbosa (b), P. brauni (c), and P. avelinoi (d).

\section{Conclusions}

The possibility to differentiate $P$. avelinoi, $P$. bigibbosa and $P$. brauni species by visual qualitative analysis of the cranium $\mu \mathrm{CT}$ images was shown. The method permits to study the osteological characteristics without sample destroying. Thus, it could be very useful to distinguish species of museum collections where there are some doubts about the identification.

\section{References}

[1] A. C. Kak and M. Slaney, Principles of Computerized Tomographic Imaging, IEEE Press Inc., N.Y., USA, (1988).

[2] S. R. Stock, Micro Computed Tomography: Methodology and Applications, CRC Press, Boca Raton - FL, USA, (2008).

[3] A. Kwet, and J. Faivovich, Proceratophrys bigibbosa species group (Anura: Leptodactylidae), with description of a new species, Copeia, 01, (2001), 203. 
[4] A. Carosini, P. Peres., M. L. Ortiz, et al., Amphibia, Anura, Cycloramphidae, Proceratophrys avelinoi Mercadal de Barrio and Barrio, 1993: distribution extension and distribution map, Check List, 6(2), (2010), 332.

[5] R. R. Santos, P. Colombo, S. B. Leonardi, et al., Amphibia, Anura, Cycloramphidae, Proceratophrys bigibbosa (Peters, 1872) and Proceratophrys brauni (Kwet and Faivovich, 2001): distribution extension and new state record, Check List, 5(4), (2009), 922.

[6] J. D. Lynch, Evolutionary relationships, osteology, and zoogeography of leptodactyloid frogs, University of Kansas Museum of Natural History Miscellaneous Publication 53, (1971), 238.

[7] SkyScan's website, www.skyscan.be (2011). 